以上「「不完全」なデータという，やや䁔昧な表現の下に，いくつかの例をあげた。「不完全」という䓂葉の 適切か否かは別として,ここで强調したいことは「ある統計的手法が成立する上に必要な要件をとり去った時に， どのような影響があるか」ということを研究することの重要性である，もちろん，すべての条件をとり去ること は，その手法自体を否定することにもなりかねないが，複数の中の1つを取り去った場合の研究は可能と思わ机 る.これは Robustness と呼ばれる領域であるうが, その研究を含めてこうした不完全なデータの解析の研究が 臨休医学の上では著しく重要なのである.

かかる問題は，すべての条件を満足した場合の研究上りは，はるかに困難なるのであることは予想されるが， その中から統計学的にみても興味ある課題が生れる可能性も秘めているように思われてならない。

\title{
5. 結，語
}

臨床医学データの特改の中から「経時性」と「不完全さ」という点をとり出し, 統計学的に関連する問題を論 じ, 応用統計学の立場からの, かかる研究の重要性を強調した.

\section{文献}

[1] B. Schneider (1976): Multivariate methods and the problem of time dependence in clinical trials, Decision Making and Medical Care, North-Holland (Amsterdam).

[2] H. L. Christl (1976): Time dependence and Bayesian approach, Decision Making and Medical Care, North-Holland (Amsterdam).

[3] P. A. Lachenbruch (1974): Discriminant analysis, Hafner Press (New York).

[4] P. A. Lachenbruch (1979) : Discriminant analyșis, Biometrics 35 (1), 69.

[5] A. K. Gupta (1952): Estimation of the mean and standard deviation of a normal population from a censored sample, Biometrika $39: 260$.

[6] S. J, Pocock (1979) : Allocation of patients to treatment in clinical trials, Biometrics $35: 183$.

[7] R. Simon (1979) : Restricted randomization design in clinical trials, Biometrics $35: 503$.

\section{開原氏の論文に対するコメント}

竹内啓 (東京大学経済学部)

報告の中で臨床データの「不完全さ」を重視し，その解析法の研究の必要性を強調されていることは，きわめ て適切であると思う。

そもそも統計データには本来「完全なるの」などは存在しないと私は思っている。るしデータの数字が詨象を 完全無欠に表現しているのであれば，統計的処理は不要である。「誤差」「変動」「擤乱」「ばらつき」「偏り」 等々のことばは, 本来統計データの不完全性を表現するための概念にほかならない. 数理統計学はガウス以来 
200 年近くの発展を通じて，このような不完全性のある側面を適切に処理する力法を開発して来た，それが「ラ ンダムな誤差」を「確率モデル」Kよって表現し，確率諭の諭理によって偶然によって生じたと見なすととので きる不完全性を処理する統計的推測の方法であることはいうまでもない.フィッシャ一の実験計画法は,データ の不完全性をこのような諭理によって処理することができるようにするための方法を与えた。 それがくり返え し，局所管理，ランダム化，そうして多因子実験の原理である.

開原氏の強調される臨林医学データの不完全性とは, 結局臨床医学データがフィッシャ一の実験計画法の論理 に適合し難い面をふくんでいることを意味していると思う，そうしてそれは臨床医学データについては本来やむ を得ないことであって，実験技術や研究者の統計的知識の不足の責任にすべきことではないと思う．といらのは 臨床医学データの対象は, 本来一人一人が医者がその治療漬任を負っている患者であって，単なる実験素材で はないからであり，患者本人の健康上の利益が, 实験データによって得られる情報の価值よりも, 元来は優先さ れねばならないからである。このことはランダム化や，ある種の対照実験，要因実験の可能性を制限することに なるのはやむを得ない，むちろんこの点においても，具体的な臨床の現場で，直接本人の治療に有効なこと以外 は一切すべきではないというほど敩密主義が守られているわけでるないし，また医学の人類全体に対する貢献と いう面から見てそれが正しいといらわけでもないが，しかし医学に拉いては，実験の「科学的論理」だけですべ てを律することができないことは重視しなければならない。薬効検定などで重視されているいわゆる二重盲検法 にしても，その適用可能性には一定の限界があって，それを越え礼ば医学偷理上問題であるといるねばならない で岁ろう．いわんや薬害をしらべるための人体実駼などを行うことは，特別の例外的な場合を除いて許されない ことはいうまでもない．この点を補うための動物実験にしても，その結果を人間に外挿する点には，方法上また 別個の問題があることも強調されねばならない。

したがって，医学研究者や実験技術者に対して統計学の基礎知識を教育普及させることによって，データの 「さけられる不完全性」をできる限り除くことは重要であるが，乙かし臨床医学データには「さけられない不完 全性」があり，その中にはフィッシャー流の実験計画法の論理によっては扱らことのできない部分むあることは 正しく認識されねばならない，そうして統計学の側からは，既成の論理にもとついて「あるべきデータ」の形を 押しつけるのではなく，むしろ臨床データの性質上，さけることのできな「不完全性」を注意深く検討して， それに適した処理法を開発しなければならない，開原氏がいわれるように「臨㦿医学データは統計学的に著しく 扱いにくいデータである」とす礼ば，その責任の少くとも一半は統計学の側にあるいわねばならないのであ る.

データの「不完全性」には二つの面がある。一つは対象のある面についての情報をまったく，あるいは惊とん ど失わせるようなものであり，むう一つは対象についての情報を失わせるものではないがそれを混乱させ，デー タとの結びつきを複雑にするようなるのである．この二つの区別は重要であって，第一の場合にはデータをどの ように処理加工しても，そこから有益な情報は得られない.すべてのデータに未知の一様な「偏り」がある場合 がそれである。より具体的にはたとえば動物と人間では生理的反応に大きな美があるのに，動物実験だけの結果 から人間についての効果を見ようとする場合などである。統計学の一つの任務は，情報が得られない場合につい ては，そのことを明確にし，「木によって魚を求める」ことのない上う勧告することである．これに対して第二 の場合には，適切な統計的処理によって必要な情報をとり出すことが，原理的には可能である．その場合重要な ことは適切な特性値をとり出すこと，それについて適当なモデルを想定することである。この場合データそのも のについて直接複雑なモデルを想定するよりも，適切な特性值を選んだり，变数变換を行った後，簡単なモデル をあてはめる力が有効である場合が多い。 
ところで第一の場合については, 最初に考兄られることは, 実験や観測の方法を変えて必要な情報が得られる ようにすることであるが,てかし実はそのよらな実験を行らことが非常に困難であることも多い。そのよな場合 には，モデルの棈造，あるいはその前提となっている理諭構成そのものを再検討して，データによって榆証，亦 るいは推定することが容易になるような形にモデルを作り直すことが望ましい場合む少なくない。たとえば開原 氏の紹介している, multi-compartment model では compartment の数が 3 以上になると，モデルの母数を推 定することが事実上不可能になることは，かつて数値的に検討して確かめたことがある（Mathematical Bioscience, 1972). したがって compartment の数が3か4かをデータから検出しょらなどとしても，それは無理 である、この上うな場合には，実験の方法をまったく変えるか。そうでなければ理論構成そのものを変えて，む っと情報が得やすい形化モデルを作る必要がある.

複雑な情報構造の問題については，2つの種類があるように思われる。一つはこれまで理論的に报われて来た ようなモデルではその構造を表現できず，新たなタイプのモデルを考えねばならない場合である。開原氏のあげ られた「三次元データ」あるいはより具体的にい党ば「多变量時系列データ」がその例である。とくにそれがあ る処置後の時間的観測データのような本質的に非定常的な時系列データの場合が重要である．これについては一 般的な理論の開発がきわめて不十分であり，より一層の研究が必要である。このような場合に適㽖なモデルの想 定なしに、これまでに作られた手法を「いいかげん」に適用しても十分な結果は得られないであるう。基本的に はこのようなデータについては次のようなモデルが想定できると思う.すなわら $y_{t t}$ を第 $i$ 個人の $t$ 期にお汁

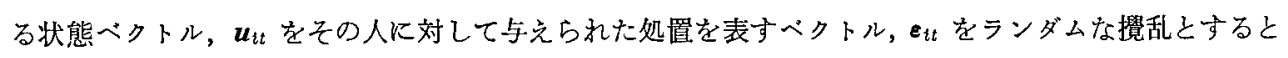

$$
\boldsymbol{y}_{t t}=f\left(\boldsymbol{y}_{t t-1}, \boldsymbol{y}_{t-2}, \cdots \cdots, \boldsymbol{u}_{\imath t}, \boldsymbol{\varepsilon}_{t t}, \boldsymbol{\theta}_{i}\right)
$$

と表すことができる.ただしここで $\theta_{2}$ はその人の特性を表す母数べクトルである．もし必要ならば適当な变数 变換を行った後，上記の関係を線形化できるならば，

$$
\boldsymbol{y}_{t t}=\boldsymbol{\beta}_{t 1}+A_{t 1} \boldsymbol{y}_{t t-1}+A_{t 2} \boldsymbol{y}_{t t-2}+\cdots \cdots+B_{i} \boldsymbol{u}_{t t}+\boldsymbol{\varepsilon}_{t t}
$$

といら形の自己回帰型モデルが得られるであるら.てうしてさらにここに係数行列の形についてのアプリオリな 仮定を加えることができるならば，構造推定や個人盖についての検定を行うことができるであるう。このような モデルは時系列計量経済モデルに近い性質を持つ. ただ一つの特徵は多くの場合, 制御变数 $\boldsymbol{u}_{t t}$ が時間的になめ らかな変動をせず，不連続に变わることである，このことは推定問題を単純化することが多い. multi-compartment model 注自己回帰モデルと数学的には同等になるとい光るが，後者の方が統計的には扱いやすい.

複雑さの第 2 の種類は，モデルの構造が基本的には知られていて，ただそれが非常に複雑になっている場合で ある. “missing data” (それも多数の欠測がある場合)，“censored data”などがその例である、これについては 解析法についても原則的には問題はなく, 多くの場合最尤推定, 尤度比検定を(「偏りの補正」等を行った上で) 適用すれば十分である.ただ現奏の解析に打いては，計算が著しく面倒になる可能性があるが，最近のコンピェ 一ターの発達を考えれば，単なる計算の困蜼はあまり問題ではない。

問題はむしろ2つの点にある. 第一は「複雑すぎる」モデルはさけ放ばならないということである.偏りをふ くむことがわかっていてる単純なモデルの方が望ましい場合が少くない，この点の選択において赤池弘次氏の情 報量基準 AIC は1つの指針を与克る. 第二は分布型の問題である. 多くの場合について，とくに多変量解析沉 ついて想定される正規分布の仮定は，現実には必ずしもあてはまるとは限らないこの揚合正規分布以外の分布 型を明確に定めることもできないから，結局正規分布から離れた分布の下でる著しく効率が下らないような方法 を求めなければならない。これが robustness の問題である。これについてはもっとも簡単なモデル以外の場合 についてはまだ十分しらべられていないが，一般的に異常值 outlyerの存在を注意深くチェックしてその影響を 
除けば，分布の非正規性の極端な影響は一応さけることができるといってよい。

なおこの問題と関連して標本の non-randomness が重大でする. random sample の仮定からの业離は，僅か であっても結論炕大きな偏りをもたらす恐れがあるのみならず，そのこと自体を標本によってチェックすること は不可能に近い，た之えば標本観測值の間に相関が存在する場合，相関係数が小さくても，母数についての情報 が著しく落ちることがあり，しかもそのような相関の存在を検出することは難しい，

このような場合観测值の randomness を保証するような実験計画を適用することは，臨床医学に扎いては著 しく困難であることはすでにのべた通りであるしたがって non-randomness の可能性を注意深く取り入れた モデルを作って解析を進めなければならない。

一般的にいって開原氏のいわれたことは，臨床医学データの特徵を的確に指摘し今後の研究の方向について適 切な示唆を与光るものであると思う。 